\title{
Properties of Proteus mirabilis and Providence Spheroplasts
}

\author{
By A. J. VAN RENSBURG \\ Department of Microbiology, University of Pretoria, Pretoria, South Africa
}

(Accepted for publication 3I January 1969)

SUMMARY

Proteus mirabilis strain I 3 and Providence strain NCTC92 I I were converted to osmotically sensitive spheroplasts by growth in the presence of penicillin or glycine in sucrose-supplemented or unsupplemented medium. Lysozyme in the presence of tris and ethylenediaminetetra-acetic acid (EDTA) converted both these strains to spheroplasts. Penicillin spheroplasts could be stabilized with sucrose, streptomycin, spermine or di-valent cations. Electron micrographs of these spheroplasts demonstrated that the outer layer of the bacterial cell wall was retained. Penicillin-induced spheroplasts possessed receptor sites for bacteriophages.

\section{INTRODUCTION}

Bacterial protoplasts have been reviewed by McQuillen (1956, 1960), Weibull (I958) and Martin (1963). The term protoplast is limited to a cell devoid of cell wall (McQuillen, I960). Cells converted to osmotic sensitive spherical bodies which retain nonrigid cell walls are called spheroplasts (Tulasne, Minck, Kirn \& Krembel, I960; McQuillen, 1960). The cell walls of Bacillus megaterium, Sarcina lutea and Micrococcus lysodeikticus consist predominantly of mucopolymer (Salton, 1960). The cell wall of Escherichia coli consists of a superficial lipoprotein, an intermediate lipopolysaccharide and an innermost rigid mucopolymer layer (Weidel, Frank \& Martin, 1960). Salton \& Shafa (1958) emphasized that cell walls of Gram-negative bacteria contain the mucopeptide-substrate of lysozyme as a minor component. In $E$. coli and Proteus mirabilis the lipoprotein and lipopolysaccharide layers are anchored to the mucopolymer in an intricate mosaic of functional surface sites (Hofschneider \& Martin, 1968). Weidel et al. (1960) also showed that the receptor sites for bacteriophages were located in the lipoprotein and lipopolysaccharide layers and that phages did not adsorb to the rigid layer. Kellenberger \& Ryter (1958) provided microscopic proof for the multi-layered cell wall in $E$. coli. They demonstrated a cell wall in which two electron dense layers were separated by a less dense layer. Depolymerization of the mucopolymer which provides rigidity to the cell wall is necessary for conversion to spheroplasts. This can be accomplished by lysozyme which acts on $\beta$-I, $4-N$-acetylglucosamides (Salton \& Ghuysen, 1959) or penicillin (Lederberg, 1956, 1957) which inhibits mucopolymer synthesis (Park \& Strominger, 1957). To explain the action of penicillin on synthesized mucopolymer the presence of two enzymes in the cell was suggested by Weidel et al. (1960). One splits certain bonds in the mucopolymer while the other resynthesizes mucopolymer in these gaps. Bayer (I967) observed the formation of bag-like protrusions of the soft layers and the simultaneous appearance of gaps in the proteinaceous portion of the rigid layer during penicillin treatment of $E$. coli. 
Weibull $(1953 a, b)$ converted cells of Bacillus megaterium suspended in 0.15 to $0.2 \mathrm{M}$-sucrose to protoplasts by treatment with lysozyme. These protoplasts did not adsorb bacteriophages (Weibull, I953a) and were devoid of the cell-wall component diaminopimelic acid (Weibull \& Bergström, I958). Fukuda (196I), however, described the adsorption of bacteriophages to lysozyme-induced protoplasts of several strains of $B$. subtilis, suggesting incomplete removal of cell-wall components. To enhance the effect of lysozyme on Gram-negative bacteria additional procedures were employed. These included freezing and thawing (Kohn, 1960), incubation at alkaline pH (Zinder \& Arndt, 1956) and the addition of the chelating agent ethylenediaminetetra-acetic acid (EDTA) in tris buffer (Repaske, 1956, 1958). Repaske (1958) reported differences in susceptibility of Gram-negative bacteria to lysis by the combined effects of lysozyme, EDTA and tris buffer. Escherichia coli strains $\mathbf{B}$ and $\mathrm{H}$, Pseudomonas aeruginosa, $P$. fluorescens and Azotobacter vinelandii were rapidly lysed. Proteus vulgaris was slightly lysed while Aerobacter aerogenes and Serratia marcescans were not affected. Gebicki \& James (1958) proved A. aerogenes to be resistant to lysozyme even in the presence of EDTA. Voss (1964) showed that lysis of E. coli and P. aeruginosa by lysozyme in the presence of EDTA and tris buffer was not necessarily preceded by spheroplast formation. These organisms were converted to osmotically fragile rods rather than spheres. Jeynes (1957) prepared protoplasts of Vibrio cholera, Salmonella typhi, S. typhimurium and S. paratyphi by growth in liquid medium containing glycine.

Tabor (196I) reported that $\mathrm{IO}^{-3} \mathrm{M}$-spermine or spermidine prevented lysis of lysozyme-induced protoplasts of Escherichia coli strains B and w and Micrococcus lysodeikticus in hypotonic media. Stabilization of penicillin spheroplasts of $E$. coli w was less complete. Streptomycin and $\mathrm{Ca}^{2+}$ ions were also effective stabilizers, but $\mathrm{Mg}^{2+}$ ions as well as mono-valent cations had no protective properties at $10^{-3} \mathrm{M}$-concentrations with slight protection at higher concentrations. Indge (I968) found that $\mathrm{K}^{+}, \mathrm{Na}^{+}$ $\mathrm{Mg}^{2+}$ and spermidine inhibited the effect of chelating agents on lysis of yeast protoplasts.

As a preliminary to the study of transfection (Spizizen, Reilly \& Evans, 1966) in Proteus and Providence strains the properties of spheroplasts of these organisms were investigated and are reported here.

\section{METHODS}

Media. Difco nutrient broth was used. The spheroplasting medium consisted of nutrient broth supplemented with $0.5 \mathrm{M}$-sucrose and $0.2 \%(\mathrm{w} / \mathrm{v}) \mathrm{MgSO}_{4} .7 \mathrm{H}_{2} \mathrm{O}$. Tris buffer (0.067 M, pH 8.0), lysozyme (Sigma) and ethylenediaminetetra-acetic acid (Merck) were used. Incubation was at $37^{\circ}$.

Bacteria and bacteriophages. Providence strain NCTC92II (Coetzee, 1963a), Proteus mirabilis strain I3 $_{3}$ (Coetzee \& Sacks, I960) and Escherichia coli strain B were used. For phage adsorption studies the temperate Providence bacteriophage PL 25 (Coetzee, 1963a) and the virulent $P$. mirabilis bacteriophage 13vir (Prozesky, De Klerk \& Coetzee, 1965) were used.

Lysozyme +EDTA spheroplasts. The spheroplasts of Escherichia coli в were prepared according to Fraser \& Mahler (1957) as modified by Fraser, Mahler, Shug \& Thomas (1957). Spheroplasts of Proteus mirabilis I3 and Providence NCTC92 I I were prepared from overnight cultures in nutrient broth. Organisms were harvested by centrifugation of $10 \mathrm{ml}$. of the cultures at $2000 \mathrm{~g}$ for $30 \mathrm{~min}$., washed twice with $0.067 \mathrm{M}$-tris and 
resuspended in I $\mathrm{ml}$. tris containing $0.5 \mathrm{M}$-sucrose. To the suspension of the Providence strain $0.2 \mathrm{ml}$. lysozyme ( $2 \mathrm{mg} . / \mathrm{ml}$.) and after $3 \mathrm{~min}$. $0.05 \mathrm{ml}$. EDTA $(4 \%$, w/v) were added. For the $P$. mirabilis strain $0.4 \mathrm{ml}$. lysozyme and $0 . \mathrm{I} \mathrm{ml}$. EDTA were used. The mixtures were then incubated for $8 \mathrm{~min}$. followed by a I/5 dilution with nutrient broth. The preparations were examined in a phase-contrast microscope.

Glycine spheroplasts. These were obtained by adding $5 \mathrm{ml}$. of an overnight culture to $100 \mathrm{ml}$. nutrient broth supplemented with $0.5 \mathrm{M}$-sucrose, $0.2 \% \mathrm{MgSO}_{4} \cdot 7 \mathrm{H}_{2} \mathrm{O}$ and glycine $(3 \%, \mathrm{w} / \mathrm{v})$. The cultures were aerated. Samples were removed at intervals and examined by phase-contrast microscopy. After incubation for $5 \mathrm{hr}$ the spheroplasts were collected by centrifugation at $2000 \mathrm{~g}$ for $30 \mathrm{~min}$.

Penicillinspheroplasts. Spheroplasts of Escherichia coli $\mathrm{B}$ were prepared by the method of Lederberg (1956). Penicillin spheroplasts of Providence and Proteus mirabilis strains were obtained by diluting $10 \mathrm{ml}$. of an overnight culture in $100 \mathrm{ml}$. spheroplasting medium. Penicillin G (I00 to I0,000 u./ml.) was added to the medium which was then incubated with aeration. Samples were removed at intervals, examined microscopically and plated on MacConkey agar to determine colony-forming bacteria. The method was varied by substituting unsupplemented nutrient broth for the spheroplasting medium. Spheroplasts were counted in a Petroff-Hauser chamber with the use of a phase-contrast microscope. Spheroplasts were harvested after 3 -hr incubation.

Osmotic sensitivity. Duplicate samples of lysozyme, glycine and penicillin spheroplasts were collected by centrifugation at $2000 \mathrm{~g}$ for $30 \mathrm{~min}$. The pellets were resuspended in equal volumes of $0.5 \mathrm{M}$-sucrose and deionized water respectively. Extinctions at $650 \mathrm{~m} \mu$ were determined within Io min. in a Hitachi Elmer-Perkin spectroophotometer. Stability of spheroplasts prepared in unsupplemented medium were determined by resuspending in deionized water and nutrient broth.

Stabilization of penicillin spheroplasts. After incubation for $3 \mathrm{hr}$ the penicillin spheroplasts were collected by centrifugation at $2000 \mathrm{~g}$ for $30 \mathrm{~min}$. The pellets were suspended in equal volumes of $0.5 \mathrm{M}$-sucrose, water, streptomycin sulphate $\left(\mathrm{IO}^{-3} \mathrm{M}\right)$, $\mathrm{CaCl}_{2}\left(\mathrm{IO}^{-2}, \mathrm{IO}^{-3} \mathrm{M}\right)$, spermine $\left(\mathrm{IO}^{-3}, \mathrm{IO}^{-4}, \mathrm{IO}^{-5} \mathrm{M}\right), \mathrm{MgCl}_{2}\left(\mathrm{IO}^{-2}, \mathrm{IO}^{-3} \mathrm{M}\right), \mathrm{NaCl}\left(\mathrm{IO}^{-2} \mathrm{M}\right)$ and unsupplemented nutrient broth. Extinctions of the suspensions at 650 and $260 \mathrm{~m} \mu$ were determined within Io min. after suspending in a Hitachi Elmer-Perkin spectrophotometer. The suspensions were also examined microscopically.

Electron microscopy. Penicillin spheroplasts of Providence and Proteus mirabilis were prepared and collected as above. Fixation was done in osmium tetroxide (Kellenberger \& Ryter, 1958). Preparations were stained in uranyl acetate before dehydration through a graded acetone series and embedding in Epon-Araldite. Electron microscopy was performed in a Philips EM 200 electron microscope.

Phage adsorption. Penicillin spheroplasts of Proteus mirabilis and Providence were collected by centrifugation and resuspended in $0.5 \mathrm{M}$-sucrose. Bacteriophages PL 25 and I 3 vir at multiplicities of input of 100 to 300 were added to spheroplasts of Providence strain NCTC92II and $P$. mirabilis strain I3, respectively. After incubation for Io min. the interaction was stopped by the addition of osmium tetroxide. Staining and embedding were done as before. 


\section{RESULTS}

\section{Lysozyme +EDTA spheroplasts}

At least $99 \%$ of the Providence organisms were converted to spherical forms by this method. Proteus mirabilis I 3 was more resistant to lysozyme-EDTA treatment and higher concentrations of lysozyme $(0.4 \mathrm{ml}$.) and EDTA (0.I ml.) were necessary for optimum yields. For this strain conversion to spherical forms was never more than $80 \%$ and was not improved by further increase in the concentrations of lysozyme or EDTA.

\section{Glycine spheroplasts}

Glycine at concentrations of 3 to $5 \%(\mathrm{w} / \mathrm{v})$ proved an effective inducer of spheroplasts. In both strains the first small spheroplasts were observed at $40 \mathrm{~min}$. At $4 \mathrm{hr}$ all the cells were spherical and incubation for $\mathrm{r} 2 \mathrm{hr}$ yielded a dense-culture of spheroplasts.

\section{Penicillin spheroplasts}

Incubation of the Proteus mirabilis and Providence strains in the presence of penicillin caused the rod-shaped cells to develop swellings centrally or terminally. The swellings enlarged to form spheres with remnants of rods protruding. The sequence of forms in both $P$. mirabilis and Providence was similar to those described for $P$. vulgaris and Escherichia coli (Liebermeister \& Kellenberger, 1956; Hahn \& Ciak, 1957). The concentration of penicillin was not critical and 500 to $10,000 \mathrm{u} . / \mathrm{ml}$. were equally efficient. Incubation of the $P$. mirabilis and Providence strains in unsupported nutrient broth in the presence of high concentrations of penicillin $(500 \mathrm{u} . / \mathrm{ml}$. for the $P$. mirabilis and $3000 \mathrm{u} . / \mathrm{ml}$. for the Providence strain) also resulted in dense cultures of spheroplasts which were identical to those described above. Lower concentrations of penicillin (2000 and $500 \mathrm{u}$. $/ \mathrm{ml}$. respectively) caused the formation of spherical as well as filamentous forms in both the organisms (Fleming, Voureka, Kramer, Hughes I950). The $E$. coli strain treated similarly underwent complete and rapid lysis. Irrespective of whether the spheroplasts were prepared in unsupported nutrient broth or in spheroplasting medium all spheroplasts lysed in water. While the spheroplasts prepared in spheroplasting medium lysed when resuspended in unsupported nutrient broth those obtained in nutrient broth were stable in the latter medium.

\section{Stability of penicillin spheroplasts}

On account of the efficiency and reproducibility of the penicillin method of spheroplast formation these spheroplasts prepared in spheroplasting medium were examined in greater detail. As indicated in Table $I$ the spheroplasts were stabilized when suspended in $0.5 \mathrm{M}$-sucrose. Streptomycin sulphate $\left(\mathrm{IO}^{-3} \mathrm{M}\right), \mathrm{CaCl}_{2}\left(\mathrm{IO}^{-3} \mathrm{M}\right)$ and $\mathrm{MgCl}_{2}$ $\left(\mathrm{IO}^{-3} \mathrm{M}\right)$ were effective stabilizers while $\mathrm{NaCl}\left(\mathrm{IO}^{-2} \mathrm{M}\right)$ provided very little support. Spermine at $\mathrm{IO}^{-3} \mathrm{M}$ was a good stabilizer for penicillin spheroplasts of Escherichia coli $\mathrm{B}$. Maximal stabilization of penicillin-induced spheroplasts of Proteus mirabilis 13 and Providence NCTC92I I was obtained at a spermine concentration of $10^{-4} \mathrm{M}$. Higher concentrations caused aggregation of the spheroplasts while low concentrations provided no protection against lysis. Suspension in water caused rapid lysis of the spheroplasts with a drastic decrease in optical density at $650 \mathrm{~m} \mu$ and the presence of membranous structures detected by phase-contrast microscopy. 


\section{Table I. Stability of penicillin induced spheroplasts}

Ten $\mathrm{ml}$. of penicillin spheroplasts prepared in sucrose-supplemented medium were centrifuged at $2000 \mathrm{~g}$ for $30 \mathrm{~min}$. and resuspended in equal volumes of the different solutions.

\begin{tabular}{|c|c|c|c|}
\hline Suspending medium (M) & $\begin{array}{l}\text { Providence } \\
\text { NCTC 92 I I }\end{array}$ & $\begin{array}{c}\text { Proteus } \\
\text { mirabilis I3 }\end{array}$ & $\begin{array}{l}\text { Escherichia } \\
\text { coli } \mathrm{B}\end{array}$ \\
\hline Sucrose, 0.5 & $0.52^{*}$ & 0.48 & 0.64 \\
\hline Water & 0.16 & 0.14 & 0.095 \\
\hline Streptomycin sulphate, $\mathrm{IO}^{-3}$ & 0.49 & 0.32 & 0.60 \\
\hline $\mathrm{CaCl}_{2}$ & 0.34 & 0.26 & 0.36 \\
\hline Spermine, $10^{-3}$ & 0.29 & $0 \cdot 155$ & 0.45 \\
\hline Spermine, $10^{-4}$ & 0.50 & 0.42 & 0.16 \\
\hline Spermine, $10^{-5}$ & 0.24 & 0.13 & 0.08 \\
\hline $\mathrm{MgCl}_{2}, \mathrm{IO}^{-3}$ & $0.3 \mathrm{I}$ & 0.24 & 0.32 \\
\hline $\mathrm{NaCl}, 10^{-2}$ & 0.26 & 0.16 & 0.27 \\
\hline Nutrient broth & 0.29 & 0.14 & $0 \cdot \mathrm{II}$ \\
\hline Sucrose, $0.5 \dagger$ & 0.38 & 0.36 & - \\
\hline Nutrient broth $\uparrow$ & 0.38 & 0.36 & - \\
\hline
\end{tabular}

\section{Electron microscopy}

A section of a penicillin-induced spheroplast of Providence strain NCTC92II is shown in Pl. I, fig. I. The cell contents are surrounded by two superimposed integuments identical in appearance. The innermost layer adheres closely to the cytoplasmic mass and has the triple layer structure of a unit membrane (Robertson, 1959). This layer corresponds to the cytoplasmic membrane in Escherichia coli (Kellenberger \& Ryter, 1958). The outer triple layer is located in a position corresponding to the cell wall of E. coli and Proteus mirabilis (Hofschneider \& Martin, 1968). Areas where the outer triple membrane is stripped from the inner membrane can be seen. No structural differences were detected between penicillin spheroplasts prepared in sucrose-supplemented or unsupplemented medium. In Pl. I, fig. 2, bacteriophage PL 25 is adsorbed to spheroplasts of the Providence strain. Similar results were obtained in the P. mirabilis I3-phage I3vir system.

\section{DISCUSSION}

The spherical bodies of Providence and Proteus mirabilis described here correspond to spheroplasts on grounds of morphology and osmotic sensitivity. Lysozyme in the presence of the chelating agent EDTA converted cells of Providence NCTC92 I to spheroplasts but $P$. mirabilis $\mathrm{I} 3$ was more resistant to the combined action of these reagents. This suggests differences in the cell walls of these closely related species $($ Coetzee, $1963 b$ ). Glycine and penicillin were equally efficient in the production of spheroplasts in the Providence and $P$. mirabilis strains. These results are in agreement with the postulate of Park (1958) that both glycine and penicillin inhibit synthesis of cell-wall material in a manner which causes accumulation of uridine-5'-pyrophosphate derivatives. The reason why Proteus and Providence spheroplasts can be prepared in nutrient broth unsupported by sucrose is obscure. No morphological differences were detected between spheroplasts prepared in sucrose-supplemented or plain nutrient broth. Preparation in the latter medium may select for a different type of cell which is less fragile. The P. mirabilis and Providence strains differ in this respect from Escherichia 
coli and this behaviour may indicate that cell walls of the former organisms are less affected by penicillin than those of $E$. coli.

The mechanism of stabilization of spheroplasts by spermine is not clear, but Mager (I959) suggested that binding of the negatively charged polyamine molecules is a prerequisite for its action.

Electron micrographs did not reveal morphological differences in spheroplasts obtained by the lysozyme-EDTA, penicillin or glycine methods. They demonstrated the presence of two triple layers similar in appearance. The outer layer corresponds in position to the cell wall of normal bacteria. Electron micrographs also demonstrate the adsorption of bacteriophages to penicillin spheroplasts. This indicates that these spheroplasts retain receptor sites for bacteriophages and suggests that only the mucoprotein layer is affected during penicillin treatment. The adsorption of phages to penicillin spheroplasts supports the concept that penicillin prevents synthesis of mucopeptide (Duguid, 1946) but does not affect the lipoprotein and lipopolysaccharide which contain specific receptor sites for phages (Burnet, 1934; Jesaites \& Goebel, 1952; Oram \& Reiter, 1968). Oram \& Reiter (1968) have, however, demonstrated the inactivation of phage $\mathrm{ml} 3$ by the plasma membrane of Streptococcus lactis strain ML 3 while the cell wall did not possess inactivating properties.

This work was supported by grants from the South African Council for Scientific and Industrial Research to Professor J. N. Coetzee.

\section{REFERENCES}

BAYER, M. E. (1967). The cell wall of Escherichia coli: early effects of penicillin treatment and deprivation of diaminopimelic acid. J. gen. Microbiol. 46, 237.

BURNET, F. M. (1934). The Bacteriophages. Biol. Rev. 9, 332.

CoETzEe, J. N. (1963a). Lysogeny in Providence strains and the host-range of Providence bacteriophages. Nature, Lond. 197, 515 .

Coetzee, J. N. (I963 b). Lysogeny in Proteus rettgeri and the host-range of $P$. rettgeri and $P$. hauseri bacteriophages. J. gen. Microbiol. 31, 219.

CoETZEe, J. N. \& SACKs, T. G. (I960). Transduction of streptomycin resistance in Proteus mirabilis. J. gen. Microbiol. 23, 445 .

Duguid, J. P. (1946). The sensitivity of bacteria to the action of penicillin. Edinb. med. J. 53, 40I.

Fleming, A., Voureka, A., Kramer, I. R. H. \& Hughes, W. H. (I950). The morphology and motility of Proteus vulgaris and other organisms cultured in the presence of penicillin. J. gen. Microbiol. 4, 257.

Fraser, D. \& MAHLER, H. R. (I957). The effects of nucleases on the reproduction of T 3 bacteriophage in protoplasts of Escherichia coli. Arch. Biochem. Biophys. 69, I66.

Fraser, D., MahleR, H. R., Shug, A. L. \& Thomas, C. A. Jun. (1957). The infection of sub-cellular Escherichia coli strain B, with a DNA preparation from T2 bacteriophage. Proc. natn. Acad. Sci., U.S.A. 43, 939.

FUKUDA, S. (196I). Studies on host-specificity of Bacillus subtilis-phage (S-a), with special reference to its behaviour toward protoplasts. J. gen. appl. Microbiol. 7, I.

GeBICKI, J. M. \& JAMES, A. M. (1958). Effect of some lytic agents on Aerobacter aerogenes. Nature, Lond. 182, 725.

Hahn, F. E. \& CIAK, J. (1957). Penicillin-induced lysis of Escherichia coli. Science, N.Y. 125, I19.

Hotschnemer, P. H. \& MARTIN, H. H. (1968). Diversity of surface layers in L-forms of Proteus mirabilis. J. gen. Microbiol. 5I, 23.

INDGE, K. J. (I968). The effects of various anions and cations on the lysis of yeast protoplasts by osmotic shock. J. gen. Microbiol. 5I, 425. 
JesaITES, M. A. \& GoEbel, W. F. (1952). The chemical and anti-viral properties of somatic antigen of phase I I Shigella sonnei. J. exp. Med. 96, 409.

JEYNES, M. H. (1957). Growth and properties of bacterial protoplasts. Nature, Lond. I80, 867.

KELLENBERGER, E. \& RYTER, A. (1958). Cell wall and cytoplasmic membrane of Escherichia coli. J. Biophys. Biochem. Cytol. 4, 323.

KoHN, A. (1960). Lysis of frozen and thawed cells of Escherichia coli by lysozyme, and their conversion into spheroplasts. J. Bact. 79, 697.

Lederberg, J. (1956). Bacterial protoplasts induced by penicillin. Proc. natn. Acad. Sci. U.S.A. 42, 574.

LEDERBERG, J. (1957). Mechanism of action of penicillin. J. Bact. 73, I44.

Liebermeister, K. \& Kellenberger, E. (1956). Studien zur L-form der Bakterien. Z. Naturforsch. I1, 200.

MAGER, J. (1959). The stabilizing effect of spermine and related polyamines on bacterial protoplasts. Biochim. biophys. Acta 36, 529.

MARTIN, H. H. (1963). Bacterial protoplasts-a review. J. theoret. Biol. 5, 1.

McQuillen, K. (1956). Capabilities of bacterial protoplasts. Symp. Soc. gen. Microbiol. 6, 127.

MCQuillen, K. (1960). The Bacteria. Ed. by I. C. Gunsalus \& R. Y. Stanier, Vol. I. New York and London: Academic Press.

ORAM, J. D. \& REITER, B. (I968). The adsorption of phage to group N Streptococci. The specificity of adsorption and the location of phage receptor substances in cell-wall and plasma-membrane fractions. J. gen. Virol. 3, 103.

PARK, J. T. (1958). Inhibition of cell-wall synthesis in Staphylococcus aureus by chemicals which cause accumulation of wall precursors. Biochem. $J .70,2 \mathrm{P}$.

Park, J. T. \& Strominger, J. L. (1957). Mode of action of penicillin. Science, N.Y. I25, 99.

Prozesky, O. W., De Klerk, H. C. \& Coetzee, J. N. (1965). The morphology of Proteus bacteriophages. J. gen. Microbiol. 4r, 29.

REPASKe, R. (1956). Lysis of Gram-negative bacteria by lysozyme. Biochim. biophys. Acta 22, 189.

REPASKE, R. (1958). Lysis of Gram-negative organisms and the role of versene. Biochim. biophys. Acta 30, 225.

RoBERTSON, I. D. (1959). The ultrastructure of cell membranes. Symp. Biochem. Soc. I6, 3.

Salton, M. R. J. (1960). Microbial Cell Walls. New York and London. John Wiley and Sons, Inc.

Salton, M. R. J. \& Gruysen, J. M. (1959). The structure of di- and tetra-saccharides released from cell walls by lysozyme and Streptomyces $F_{1}$ enzyme and the $\beta(I-4) N$-acetylhexosaminidase activity of these enzymes. Biochim. biophys. Acta 36, 552 .

Salton, M. R. J. \& Shafa, F. (1958). Some changes in the surface structure of Gram-negative bacteria induced by penicillin action. Nature, Lond. r8I, I32 I.

Spizizen, J., ReIlly, B. E. \& Evans, A. H. (I966). Microbial transformation and transfection. A. Rev. Microbiol. 20, $37 \mathrm{I}$.

TABOR, C. W. (I96I). Stabilization of protoplasts and spheroplasts by spermine and other polyamines. J. Bact. 83, IIOI.

Tulasne, R., Minck, R., KIRn, A. \& Krembel, J. (1960). Delimination de la notion de formes L des bactéries: protoplasts et formes. Annls. Inst. Pasteur $99,859$.

Voss, J. G. (I964). Lysozyme lysis of Gram-negative bacteria without production of spheroplasts. J. gen. Microbiol. 35, 313.

WeIBULL, C. (1953a). The isolation of protoplasts from Bacillus megaterium by controlled treatment with lysozyme. J. Bact. 66, 688.

WeibulL, C. $(1953 b)$. Characterization of the protoplasmic constituents of Bacillus megaterium. J. Bact. 66, 696.

WeIBull, C. (I958). Bacterial protoplasts. A. Rev. Microbiol. 12, I.

WeIBULl, C. \& Bergström, L. (I958). The chemical nature of the cytoplasmic membrane and cell wall of Bacillus megaterium strain M. Biochim. biophys. Acta 30, 340.

Weidel, W., Frank, H. \& Martin, H. H. (1960). The rigid layer of the cell wall of Escherichia coli strain B. J. gen. Microbiol. 22, 158.

ZINDER, N. D. \& ARNDT, W. F. (I956). Production of protoplasts of Escherichia coli by lysozyme treatment. Proc. natn. Acad. Sci., U.S.A. 42, 586. 


\section{EXPLANATION OF PLATE}

Fig. I. Ultrathin section of a penicillin spheroplast of Providence NCTC 92I I. SW, Spheroplast wall; $\mathrm{CM}$, cytoplasmic membrane. The bar represents I $\mu$.

Fig. 2. Adsorption of phage PL25 to penicillin spheroplasts of Providence NCTC 921I. The bar represents I $\mu$. 


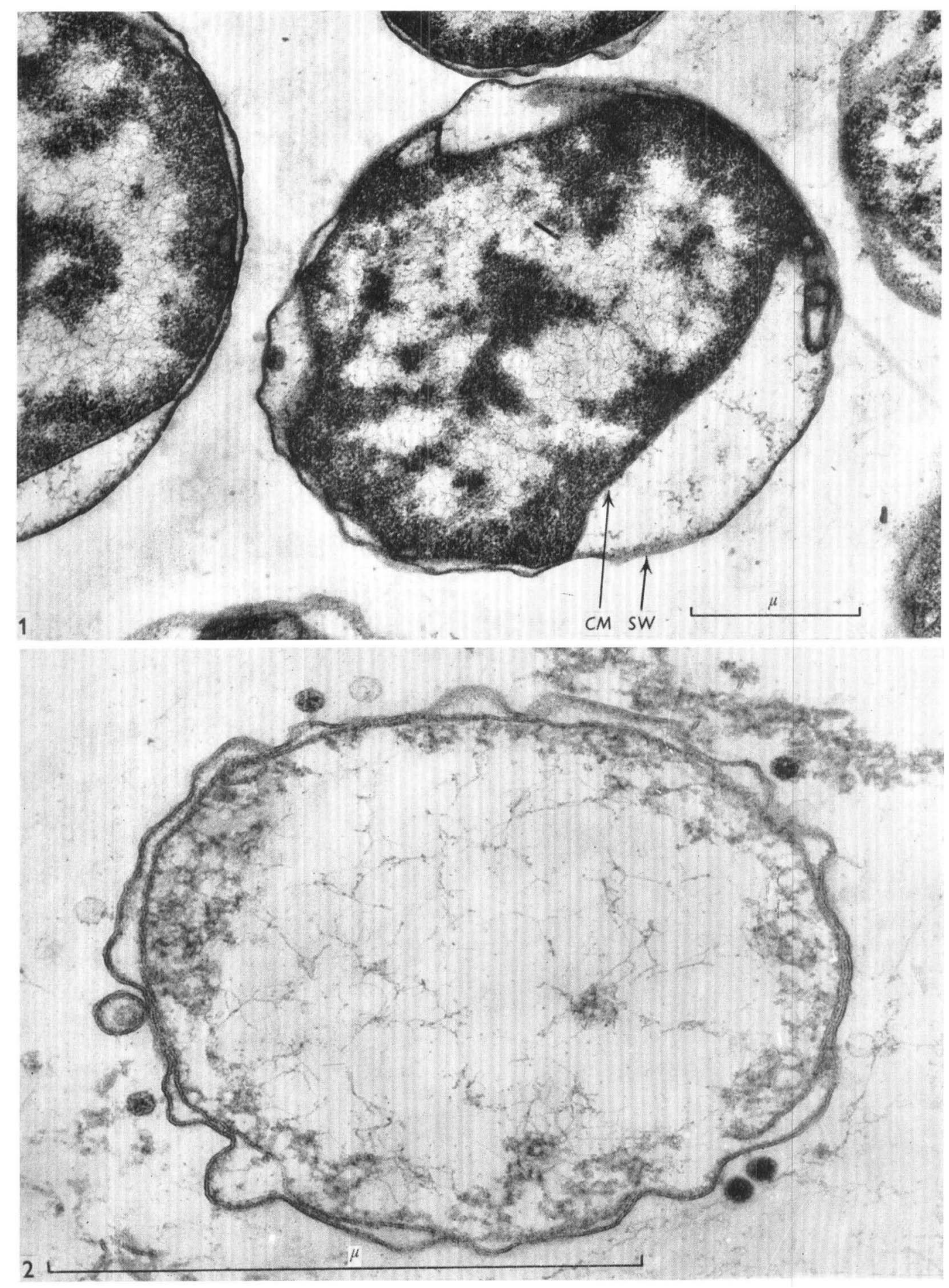

A. J. VAN RENSBURG

(Facing p. 264) 